А.Б. Скорик, С.П. Ярош

Харківський національний університет Повітряних Сил ім. І. Кожедуба, Харків

\title{
ЕВОЛЮЦІЙНИЙ РОЗВИТОК КОНЦЕПЦІЇ МЕРЕЖЕВО-ЦЕНТРИЧНИХ ВІЙН, СИСТЕМНО-КОНЦЕПТУАЛЬНІ ОСНОВИ ТЕОРІЇ ДАТА-ЦЕНТРИЧНИХ ОПЕРАЦІЙ
}

У статті коротко обговорюються основні принцฺии концеепиї мережево-центричних війн. Робиться висновок про те, щзо в умовах переходу людства до 6-го технологічного укладу виникає чергова точка біфуркації, яка визначає зміну парадигми розвитку систем ОВТ та концепиії ведення бойових дій. Аргументується необхідність розвитку теорї дата-центричної операції. Викладаються системноконцептуальні основи теорії дата-центричної операції. Запропонована онтологічна модель датаиентричної операції. Пропонується 4D-екстенціональне представлення бойового простору об'єднаних в єдину мережу систем ОВТ. Вводиться поняття дата-центричних систем, розкривається сутність методу адаптивного просторово-часового синтезу їх структури.

Ключові слова: дата-центрична операція, мережево-цฺентрична війна, 4d-екстенціоналізм, системисистем, онтологічна модель, самосинхронізація, мережево-ємні системи.

\section{Вступ}

Постановка проблеми. "Найперше, найголовніше і найважливіше в сенсі наслідків рішення, яке має прийняти державний діяч і командир - це визначити тип війни, в яку він занурюється...” (Карл фон Клаузевіц, “Про війну” [1]). Цілком очевидно, що технологічна перевага на полі бою має спиратися на передову концепцію ведення війни. В історії чимало прикладів, коли за допомогою застарілого озброєння здобувалася перемога над ворогом, який мав технічну перевагу. Але прикладів перемоги над противником, що спирається на передову концепцію ведення бойових дій, набагато менше і ті, як правило, пов'язані з “завалюванням противника трупами своїх солдатів”. У кінці ХХ століття розвиток збройних сил передових у технічному відношенні країн наблизився до певної точки біфуркації. Незважаючи на найсучасніше озброєння флот, авіація і наземні війська на полі бою стали зазнавати значних труднощів під час проведення спільних операцій. Для розуміння проблем, що виникли, звернемося до закону “необхідної різноманітності” сформульованого в роботах У.Р. Ешбі [2], який дослівно звучить так: “різноманітність поглинає різноманітність, визначає мінімальну кількість станів, необхідних для контролера, щоб управляти системою з даною кількістю станів”. Ця закономірність може бути зведена до вимоги обов'язкової відповідності між рівнями складності системи управління і рівнем складності об'єкта управління, тобто різноманітність першого має бути не менше різноманітності другого. Чим складніше об'єкт управління, тим складніше має бути система управління ним. Відсутність зазначеної відповідності в змісті системи та об'єкта управ- ління веде до зниження бойового потенціалу озброєння. Якщо система управління невиправдано ускладнена у порівнянні 3 відносно простим об'єктом, то це тягне за собою зайві витрати, дублювання функцій, додаткові комунікації, зниження оперативності тощо. 3 іншого боку, спроба управляти складним об'єктом за допомогою примітивної (за своєю структурою, функціям, методам, інформаційним технологіям) системи управління також неминуче призведе до не повного використання бойового потенціалу озброєння [3]. Відповіддю на виникнення цієї проблеми стала поява концепції мережевоцентричної війни - network-centric warfare (NCW) [4]. За 25 років, що минули з моменту зародження цієї концепції, накопичився цілий ряд кардинальних технологічних змін. Мережевий простір став звичним для людини. У цьому достатньо легко переконатися, просто діставши свій смартфон і усвідомивши, що проблеми мереж більше не існує. Вони доступні нам буквально на кінцівках пальців. Ще років двадцять тому вважалося, що світ захоплять складні алгоритми, які будуть хитро переробляти відносно прості дані. Але виявилося, що центр ваги зусиль проектувальників зміщується до роботи зі складними даними. Світ знов підійшов до чергової точки біфуркації - вибору подальшого шляху розвитку. 3 урахуванням цього, як один із перспективних шляхів розвитку озброєння та військової техніки (ОВТ) може розглядатися створення дата-центричних систем, оптимізованих для ведення бойових дій в єдиному інформаційному просторі відповідно до концепції дата-центричних операцій (data-centric operation, DCO).

Аналіз останніх досліджень і публікацій. Концепція дата-центричних операцій повинна розг- 
лядатися виключно в рамках еволюційного розвитку концепції NCW [3-7]. Детальний аналіз теорії i принципів мережево-центричних війн i операцій проведено в [8-10]. Концепцію DCO необхідно розглядати як результат розвитку загальної теорії систем та інформаційних технологій [11-15].

Мета роботи. Мета статті - розглянути еволюційний розвиток концепції мережево-центричної війни, сформулювати і представити, виходячи 3 концептуально-системної точки зору, основні положення теорії дата-центричної операції. Ввести поняття дата-центричних систем і розкрити сутність методу адаптивного просторово-часового синтезу їх структури.

\section{Виклад основного матеріалу}

Авторами концепції network-centric warfare вважаються віце-адмірал ВМС США Артур Себровскі і Джон Горстка (A. Cebrovski. Y. Gorstka) [5].

Визначення network-centric warfare можна прочитати в роботі [4]: "NCW - це про людську і організаційну поведінку. В основі концепції мережевоцентричної війни лежить прийняття нового способу мислення - мережево-центричного, і його застосування у військових операціях. Концепція NCW фокусується на бойовій потужності, яка може бути отримана в результаті мережевої інтеграції військових формувань, які ведуть бойові дії, або організації між ними ефективного зв'язку. Вона характеризується здатністю територіально розосереджених сил (що складаються 3 окремих підрозділів) створювати високий рівень загальної обізнаності про бойовий простір, який може бути використаний за допомогою самосинхронізації та інших мережевоцентричних операцій для досягнення замислу командування". Декілька конкретизують визначення NCW ключові поняття (concepts), що приводяться в цій же роботі [4]: використання географічно розосередженої сили; високий ступінь інформованості; між суб'єктами, які беруть участь в бойових діях; налагоджений ефективний зв'язок. Додаткову інформацію про зміст концепції дають основні принципи NCW (basic tenets), сформульовані в роботі [4]: 1) надійна мережева взаємодія покращує обмін інформацією; 2) обмін інформацією і співробітництво підвищують якість інформації та обізнаність про ситуацію; 3) загальна ситуаційна обізнаність дозволяє здійснювати самосинхронізацію; 4) це, в свою чергу, значно підвищує ефективність місії. Як бачимо, визначення NCW носить достатньо розпливчастий і неконкретний характер, але саме головне, на наш погляд, це те, що Артур Себровські і Джон Горстка абсолютно категорично відзначили: в основі концепції лежить прийняття нового способу мислення, i NCW - це про людську і організаційну поведінку. При цьому автори концепції цілком відверто заявляють [4]: “правда в тому, що ми не є експер- тами 3 NCW i, що набагато важливіше, на наш погляд, ніхто не є такими". Тому настільки низький рівень скептицизму відносно до конкретного змісту концепції NCW можна розглядати як свого роду феномен. Відзначимо, що NCW як наукова концепція дуже вразлива для критики. Дуже цікава в цьому питанні критика NCW з філософської точки зору, що міститься в роботі [8]. Darryn J. Reid зазначає, що багато в чому підходи авторів NCW схожі з методом наукового пізнання сера Френсіса Бекона, що характеризується об'єктивним спостереженням, індуктивним узагальненням, емпіричним обгрунтуванням і дедуктивним пророкуванням, яке тепер називається “індуктивізмом”. Індуктивізм інтуїтивно спокусливий, Ф. Бекон пропагандував індуктивізм $з$ обіцянкою знання і влади тим, хто слідував його методам, i аналогічно NCW обіцяе практично необмежені поліпшення в бойовій потужності на основі використання цифрових мереж [8]. Однак індуктивізм не має логічного принципу, тому і концепція NCW спирається на події в “когнітивній сфеpi” [6-7], де інформація трансформується в знання, а інформаційна перевага “в перевагу в бойовій потужності”. А знання в концепції NCW пов'язано з дуже нечіткими поняттями усвідомлення і розуміння. Обгрунтованість цієї критики підтверджується тим фактом, що іiі положення викладені в доповіді конгресу США [9]. Далі, незважаючи на свою назву, в концепції NCW мережі розглядаються всього лише як засіб досягнення мети - передачі інформації, i вони $\epsilon$ сферою компетенції технічних фахівців. Концепція NCW визнає центральну роль інформації і їі потенціал як джерела бойової потужності. У роботі [4] класична система ОВТ представляється як збройна платформа, що має датчики інформації і керується стрілком (рис. 1). Зона пораження (сіра область на рис. 2) залежить від дальності дії датчика [4]. При проведенні мережево-центричної операції (рис. 3) засоби розвідки, управління та командні засоби об'єднані в мережу через цифрові канали передачі даних. Збільшення потоку інформації між окремими системами призводить до забезпечення загальної обізнаності про бойовий простір і підвищення точності інформації [4].

$\mathrm{У}$ ранніх роботах з проблематики $\mathrm{NCW}$ [4-6], автори посилаються на Закон Меткалфа, щоб описати потенційну користь мережі як функцію від розміру мережі. Закон Меткалфа заснований на тому факті, що кількість унікальних зв'язків у мережі з кількістю вузлів (n) може бути математично виражено числом $n(n-1) / 2$, яке асимптотично наближається до $n^{2}$. При цьому кількості зв'язків у NCW ставиться у відповідність кількість потенційно можливих взаємодій, що приводить авторів NCW до думки про кореляцію між бойовою потужністю і розмірами мережі. 


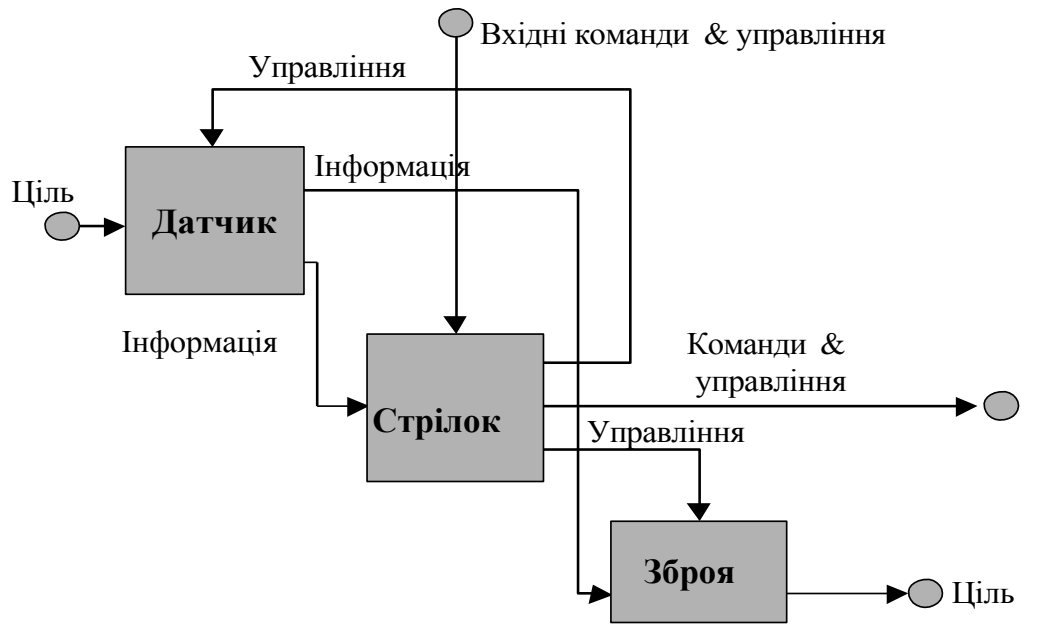

Рис. 1. Платформо-орієнтована система ОВТ Джерело: розроблено авторами за даними [4, С. 95].

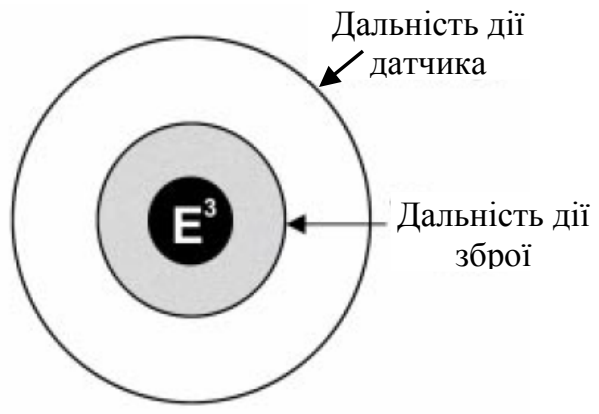

Рис. 2. Дальність дії платформо-орієнтованої системи ОВТ Джерело: розроблено авторами за даними [4, С. 97].

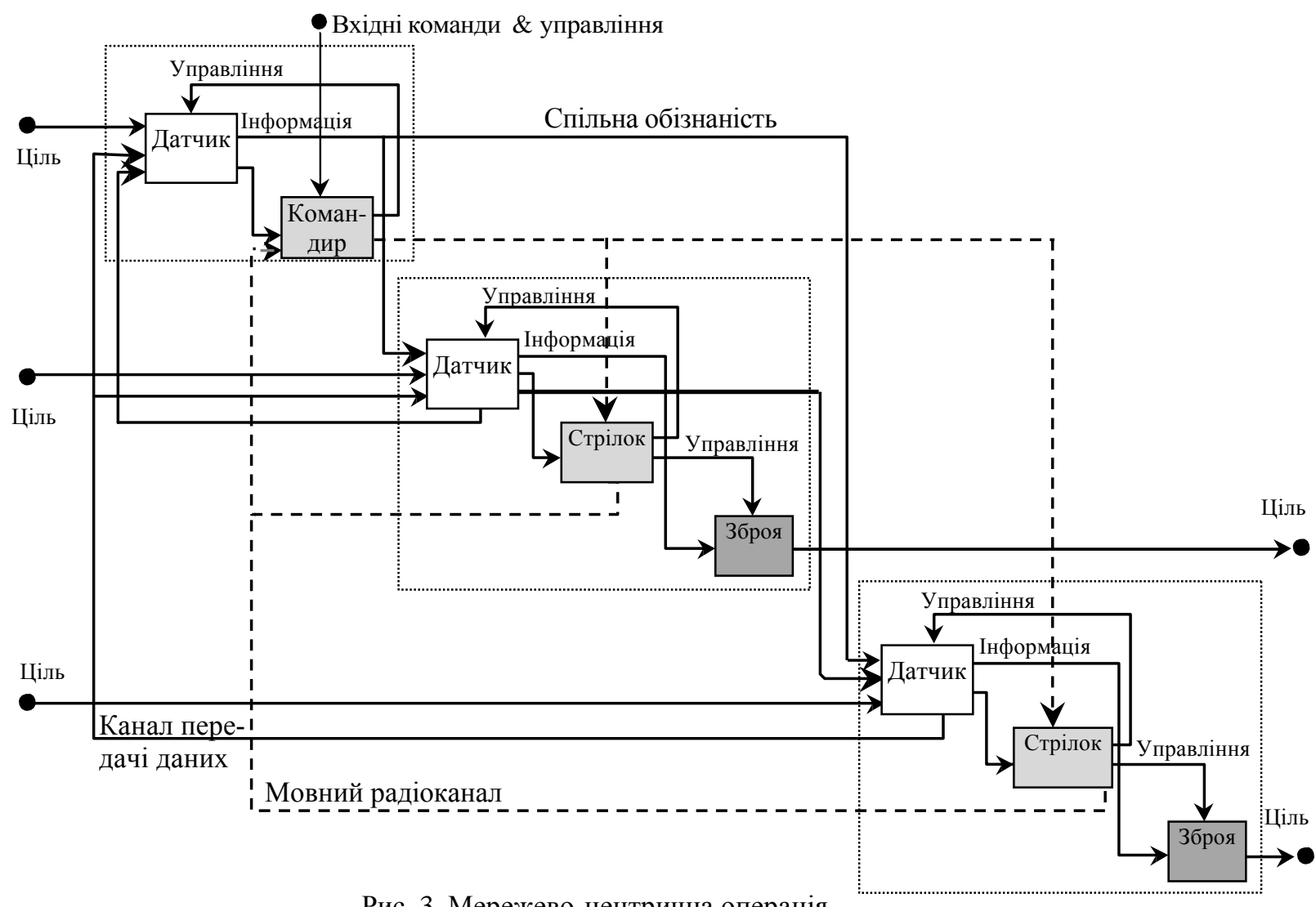

Рис. 3. Мережево-центрична операція Джерело: розроблено авторами за даними [4, С. 101]. 
Насправді, об'єднання в мережу є необхідною, але недостатньою умовою збільшення бойової потужності. Об'єднання в мережу створює лише умови для подальшої інтеграції окремих елементів мережі в цільові (fit-to-purpose) системи, оптимізовані для досягнення конкретної мети, що і забезпечує приріст бойової потужності.

Автори NCW ненавмисно примітивізують військові аспекти концепції: “ключ до розуміння ролі і взаємовідносин між суб'єктами, які беруть участь в бойових діях, полягає в тому, щоб зосередити увагу на процесах, які перетворюють необроблені дані в інформацію, а інформацію - в знання" [6]. Управління поведінкою складних систем багато в чому зводиться до самосинхронізації, причому навіть саме поняття "самосинхронізація" і ii аргументація для випадку використання систем-систем (system of systems, SoS) [14] досить дискусійні.

Самосинхронізація розглядається як спосіб взаємодії між двома або більше сутностями [3-7]. На pис. 4 [4] показані ключові елементи самосинхронізації. Передбачається, що загальна поінформованість і набір правил, що визначає бажаний результат у різних оперативних ситуаціях, дозволяють сутностям (агентам) ефективно діяти під час відсутності традиційних ієрархічних механізмів командування та управління.

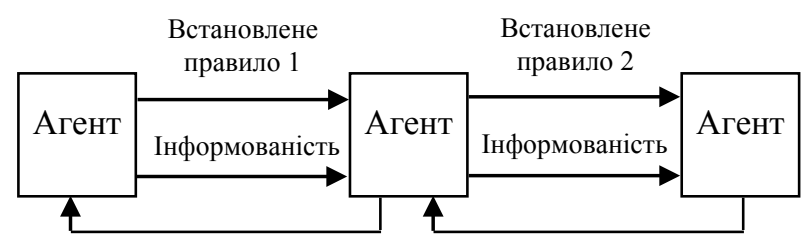

Рис. 4. Взаємодія при самосинхронізації

Джерело: розроблено авторами за даними [4, С. 176].

Парадоксальність самосинхронізації полягає в тому, що сама схема, наведена на рис. 4, ієрархічна, а процес самосинхронізації, на думку тих же автоpiв, має не глобальний, а обмежений характер: “існують визначені типи і види відносин, які за своєю природою не піддаються самосинхронізації, та інші, де застосування самосинхронізації може принести суттєву користь. Областю, де застосування самосинхронізації має значний потенціал, є певні заходи 3 ведення бойових дій, що мають допоміжні функції, такі як матеріально-технічне забезпечення, вогнева підтримка і безпосередня авіаційна підтримка" [4].

Досить спірні, з точки зору військової науки, заяви про масування ефектів замість масування сил [4]: “у міру збільшення дальності дії датчиків i зброї, а також у міру швидкого поліпшення нашої здатності передавати інформацію, ми більше не обмежені в географічному плані. Отже, для створення концентрованого ефекту більше немає необхідності концентрувати сили”.
Розширення концепції маневру розглядається, в першу чергу, як збільшення ролі маневру вогнем, у той час як роль маневру підрозділів і ОВТ, на думку авторів NCW, знижується, тому що “це дуже трудомістке та затратне завдання” [4].

Зазначені недоліки дуже серйозно підривали роль NCW як концепції ведення бойових дій. Тому в березні 2007 року в конгресі США була заслухана доповідь "Network Centric Operations: Background and Oversight Issues for Congress" [9], в якій розглянуті як позитивні, так і негативні сторони концепції NCW. Характерно, що замість концепції NCW стала використовуватися нова термінологія: теорія проведення мережево-центричних операцій (Network Centric Operations, NCO).

В основних положеннях теорії NCO стверджується, що застосування концепцій інформаційного століття для прискорення комунікацій і підвищення ситуаційної обізнаності за допомогою мережевої взаємодії підвищує як ефективність, так і результативність військових операцій. Прихильники цієї теорії стверджують, що це дозволяє бойовим підрозділам бути меншими за розміром, діяти більш незалежно і ефективно, а також виконувати місії іншого діапазону, ніж немережеві сили. Реалізація цілей командування i управління (command \& control) при проведенні NCO припускає таке [9]:

- самосинхронізацію або виконання того, що має бути зроблено без традиційних наказів;

- поліпшення розуміння намірів вищого командування;

- поліпшення розуміння оперативної ситуації на всіх рівнях командування;

- підвищення здатності використовувати колективні знання всіх американських (і коаліційних) сил для зменшення “туману війни”.

Фактично, теорія NCO як інформаційна модель синтетичного знання, в межах якої окремі поняття, гіпотези і закони втрачають колишню автономність i стають елементами цілісної системи, мало відрізняється від NCW

Революція у військовій справі [6], що стала базисом для розвитку концепції NCW, спиралася на третю промислову революцію, викликану розвитком комп'ютерів і Інтернету. У даний час відбувається четверта промислова революція, людство поступово переходить до 6-го технологічного укладу, виникає чергова точка біфуркації яка визначає зміну парадигми розвитку систем ОВТ та концепції ведення бойових дій. Один з можливих варіантів розвитку пов'язаний з розробкою нової концепції ведення датацентричної операції (Data-Centric Operations, DCO) i розробкою дата-центричних систем-систем (DSoS, або DC-систем).

Tеорія Data-Centric Operations - це нове бачення поведінки бойових систем, це перенесення 4D 
екстенсіоналізму на операційний рівень, це метаморфізм, хмарні обчислення і сервіс орієнтована архітектура не тільки у віртуальних мережах, але i на полі бою, DCO - це системи “метаморфи”, які не мають постійного “тіла” (структури), що постійно змінюються, серце яких (командні пункти) важко виявляються і недоступні противнику, частина з них може перебувати у віртуальних структурах - хмаpax. Такі бойові системи важко знищити звичайною (літальною) зброєю.

Теорія має максимально повно пояснювати відомі факти, підводячи їх під систему зв'язківзаконів, які визначаються як ті, що лежать в їх основі”. Теорія, також, це “гіпотеза, прийнята заради аргументації або дослідження, недоведене припущення”, “формулювання очевидних відносин або основні принципи певних явищ, що спостерігаються, які були перевірені в деякій мірі” [10].

Робочою гіпотезою NCO $є$ ствердження, що збройні сили, в яких реалізовано мережеве забезпечення для всіх організаційних форм і процесів - мережеві сили (networked forces) мають перевагу над традиційними [10].

За минулий з моменту формулювання даної гіпотези час іiі актуальність сильно застаріла. У теперішній час мова йде не про перемогу над менш технологічно розвинутим противником, а про протидію сучасному противнику, що проводить мережевоцентричні операції. Особливо актуальне це питання для України. Використання логічного ланцюжка досягнення військової переваги: технології - інформація - бойова міць стає менш актуальною в силу випереджаючого розвитку мережевих i комп'ютерних технологій в комерційному секторі, що визначає їх доступність всім сторонам можливого конфлікту.

Теорія дата-центричної операції, позиціонуючи себе як результат еволюційного розвитку концепції мережево-центричної війни, має максимально повно поєднати у рамках єдиних підходів систему поглядів на концепції ведення бойових дій і створення перспективних систем ОВТ, які активно розробляються найбільш розвиненими країнами світу.

До найбільш відомих 3 них слід віднести концепцію інформаційно-центристської війни - Guerre Infocentre (Франція). Ця концепція акцентує увагу на інформаційних потоках.

Бундесвер працює над концепцією індивідуальної екіпіровки солдата майбутнього - “Infanterist der Zukunft”. В останніх документах НВА Китаю зустрічається термін “інтегрована мережева і електронна війна” (Integrated Network-Electronic Warfare, INEW).

В рамках реалізації концепції INEW здійснюється розробка лазерної зброї для боротьби з космічними апаратами, навігаційних систем космічного базування, інтегрованих систем управління, зв'язку і розвідки, які повинні дозволити застосовувати балістичні ракети в неядерному оснащенні для боротьби 3 авіаносними угрупованнями.

В Україні ведуться дослідження по створенню розвідувально-управляючих інформаційних систем.

Складність створюваних систем досягла безпрецедентного рівня. Міжнародна рада з системної інженеріï (International Council on Systems Engineering, INCOSE) випустила публічний документ System Engineering Vision 2025 [12], в якому визначила, в тому числі, й рейтинг систем за їх складністю (рис. 5).

Передовим рубежем розвиту сучасної системної інженерії є дата-центричні системи-систем з організаційним децентралізованим управлінням (organizational decen-tralized governance), створювані на базі мережево-ємних систем (Network intensive).

У даному випадку поняття decentralized governance слід перекладати як “піднаглядність”, що означає, можливість децентралізованого управління системами, що входять до складу DC-систем шляхом впливу на їх поведінку [12].

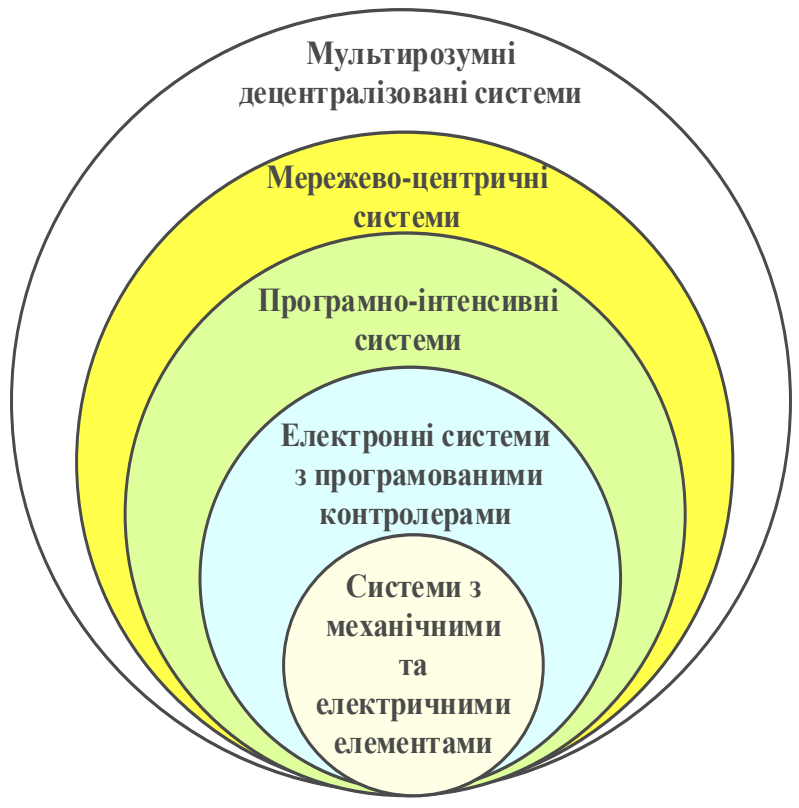

Рис. 5. Рейтинг систем за їх складністю

Джерело: розроблено авторами за даними [12].

Розвиток мережевих технологій привів світ в “еру інформації” та створив можливість ефективної реалізації моделі управління Альфреда Стоуна [13]. Одночасно з цим відбувається розвиток соціуму, але відомий вислів “перемога змінює правила гри”. Стався зсув парадигми і конкурентна перевага все більше зміщується від отримання доступу до інформації в сторону генерування знань на основі даної інформації тобто до дата-центрики [13; 15].

Впровадження мережевих технологій, широке використання гаджетів і персональних комп'ютерів 
призводять до появи у людей неокортексу [12]. Сучасна людина починає думати по іншому ніж це робила людина кінця XX-го століття. I як свого часу механістична модель системного мислення поступилася біологічній моделі і патерналістській культурі, так і тепер відбувається зсув парадигми і перехід до соціокультурних моделей побудови організацій і мультирозумних систем.

3 огляду на появу у людей неокортексу, що відповідає за вищі нервові функції, зміна соціокультурної моделі обов'язково веде до зміни онтологічної моделі опису дійсності.

У теорії NCO онтологічна модель описує взаємовідносини між суб'єктами бойового простору роблячи акцент на процесах, які перетворюють необроблені дані в інформацію, а інформацію в знання. При цьому використовується така термінологія [6].

Дані - це окремі факти, вимірювання або спостереження, яких може бути достатньо для прийняття конкретного рішення.

Інформація отримується, коли елементи даних збираються, вивіряються, зливаються і містяться в оперативний контекст.

Знання одержуються у результаті вміння використовувати інформацію для побудови і застосування пояснювальної моделі, заснованої на розумінні ситуації або явища.

Онтологічна модель NCO вважається у теперішній час застарілою. На рис. 6 запропонована онтологічна модель дата-центричної операції.

Модель DCO за термінологією співпадає 3 онтологією, що була розроблена міжнародною групою з розробки специфікацій архітектури оборонних підприємства IDEAS (International Defense Enterprise Architecture Specification) i ДСТУ ISO/IEC/IEEE 42010: 2018 “Опис архітектури”.

При розкритті поняття “умови застосування” для DSoS протиповітряної оборони (рис. 6) онтологічна модель DCO використовується разом з онтологічними моделями єдиного інформаційнобойового простору i єдиного інформаційнобойового простору [3].

Теорія ведення дата-центричних операцій, що розвивається в даний час, розглядає питання створення та функціонування в 4D просторі (3D координати / час) дата-центричних систем. Перехід від концепції NCO до концепції дата-центричної операції відображає перехід до мультирозумної соціокультурної моделі.

Як окремі питання теорії DCO розглядаються питання конфліктної взаємодії DSoS з мережевоцентричними системами.

В основі теорії Data-Centric Operations лежать концепти: метаморфізму - мінливості і гнучкого розвитку (variability \& agile development);
4D-екстенціоналізму; дуалізму дата-центричних систем-систем.

Під метаморфізмом розуміється адаптивний просторово-часовий синтез і реконфігурація структури дата-центричної системи-систем, що забезпечує DSoS найбільшу ефективність проведення операції в конкретних умовах. При цьому масштаб часу проведення операції не обмежується. Це може бути протиповітряний бій, що триває лічені хвилини, або деякий етап життєвого циклу DSoS, що триває десятки років.

Для випадку ведення протиповітряної бою метаморфізм проявляється в тому, що при порівнянній інформованості повітряно-космічних сил противника і систем зенітного ракетного прикриття, перші мають значно більші маневрені можливості, другі, маючи значно меншу рухливість, парирують цю здатність противника здійснюючи маневр вогнем, для чого відповідно до циклу стрільби (циклу Бойда) постійно перебудовують свою просторовочасову структуру.

Методологія (метод) адаптивного просторовочасового синтезу і реконфігурації структури DSoS безпосередньо пов'язана з поняття 4Dекстенціоналізма. У рамках цього підходу всі сутності / об'єкти, в першу чергу, поділяються на конкретні (індивіди) і абстрактні (класи і відносини). Індивід - це індивідуальний, унікальний об'єкт, існуючий е фізичному світі.

Існують ті об'єкти, які мають місце в просторі-часі (4D-підхід, чотиривимірний простір по Ейнштейну). Місце індивіда в 4D називається “extent”, а відповідний погляд на світ отримав назву “extensionalism”. Абстрактні об’ єкти ті, які не є індивідами - не мають протяжності в 4D, не мають екстенту. Чотиривимірний об'єкт існує в часі так само, як і у просторі.

При цьому об’єкт один, але в ньому виділяються інші об'єкти - його темпоральні частини, по аналогії зі звичайними просторовими частинами [12;15].

Такий підхід дозволяє розглядати $\mathrm{SoS}$ як єдиний об'єкт, що володіє різними темпоральними частинами. Множина систем ОВТ, об'єднаних мережею, займають деякий 3D простір.

Реконфігурація DSoS прив'язується до вирішуваних на поточний момент часу завдань. Тобто можна говорити про те, що поточна структура DSoS визначається як перетин 4D простору часовою площиною.

Події - це тривимірні “зрізи” DSoS на якийсь момент часу, такі собі тривимірні фотографії. До події був один стан DSoS, а після події - інший стан. 


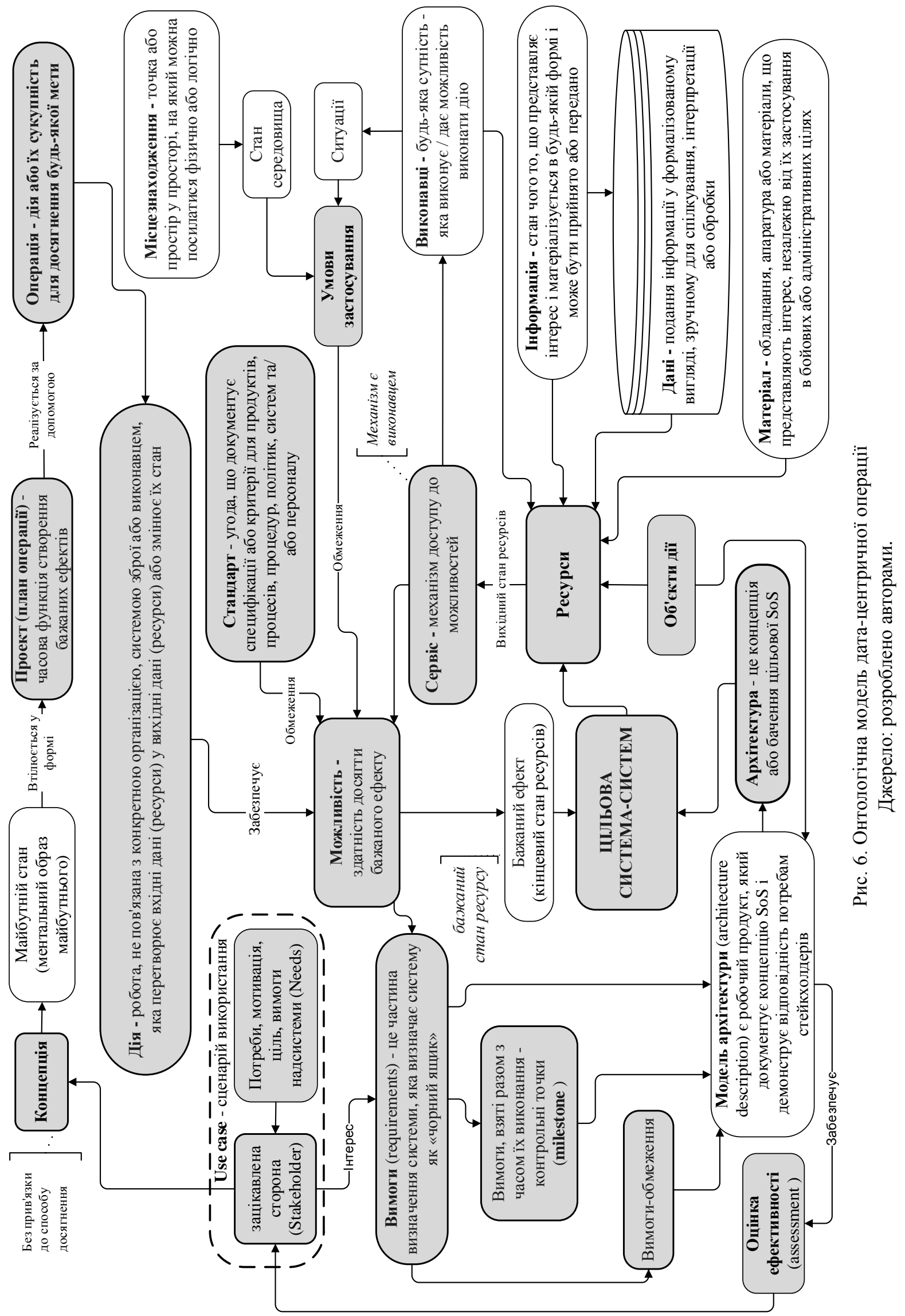


Поточна структура (часовий зріз 4D-простору) визначається необхідними на поточний часовий інтервал можливостями (Capability). Отже, DSoS має дуальний характер, iї можна розглядати одночасно i як цільову (fit-to-purpose) систему i, як мережеві ресурси. Новою якістю DC-систем стає управління конфігурацією шляхом оптимального використання і розподілу в часі мережевих ресурсів, DC-системи можуть змінювати свою структуру не тільки за рахунок власних ресурсів, але і за рахунок динамічного зв'язування мережевих ресурсів у рамках завдання, яке виконуються системою на даному проміжку часу. Окремі системи / ресурси можуть використовуватися одночасно у різних DSOS (рис. 7). Теорія DCO - припускає (основна гіпотеза), що застосування ключових факторів 6-го технологічного укладу підвищує як ефективність, так і результативність операцій за рахунок:

- переходу до парадигми мультирозумних систем на основі соціокультурної моделі;

- динамічної реконфігурації цільової системи (кластер-системи) і систем операційного оточення, залежно від зміни умов навколишнього середовища;

- розширення меж DC-системи шляхом реалізації децентралізованого управління поведінкою систем, що входять до складу DSoS.

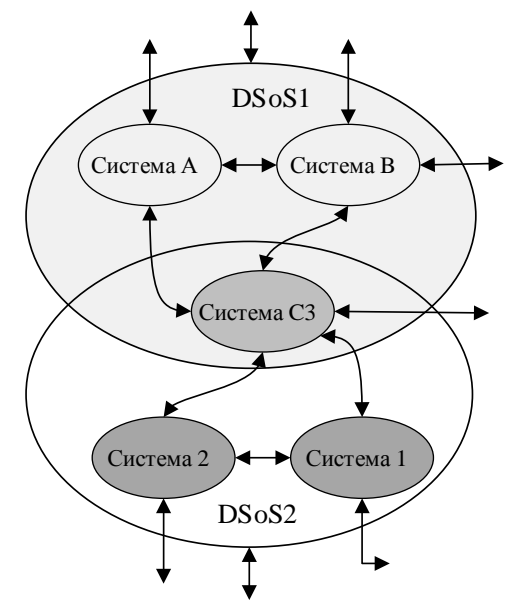

Рис. 7. Одночасне використання окремих систем / ресурсів у різних DC-системах

Джерело: розроблено авторами.
Єдиних підходів до створення мультирозумних систем на основі соціокультурних моделей ще не існує. Підходи, що є на даний час: партисипативний (заснований на партнерстві) менеджмент, багатофункціональні групи, теорія хаосу, команди, що самоорганізуються, не пропонують однозначно певних підходів до вирішення даної проблеми. Традиційні підходи до створення складних систем не забезпечують необхідної ефективності [14]. Отже, зрушення парадигми - це перехідна стадія, для якої справедливий афоризм Стаффорда Біра: “прийнятні ідеї вже не ефективні, а ефективні ідеї ще не прийнятні”.

\section{Висновки}

Внаслідок поступового переходу людства до 6го технологічного укладу, виникає чергова точка біфуркації. Конкурентна перевага все більше зміщується від отримання доступу до інформації в сторону генерування знань на основі даної інформації тобто до дата-центріки. Відбувається зміна парадигми розвитку і перехід до соціокультурних моделей побудови організацій і мультирозумних систем.

Сьогоднішне бачення мережево-центричної війни істотно відрізняється від того, що вкладалося в цю концепцію первісно. Один 3 можливих варіантів еволюційного розвитку пов'язаний з розробкою нової концепції ведення дата-центричної операції і розробкою дата-центричних систем-систем. Концепція DCO спирається на 4D-екстенціональне уявлення бойового простору систем ОВТ, об'єднаних в єдину мережу. Множина зразків озброєння, об'єднані мережею, займають деякий 3D простір. Збірка цільової системи (кластер-системи) для виконання конкретної функції / завдання здійснюється динамічно в реальному масштабі часу.

Окремі одиниці зброї (системи), що входять до складу DSoS розглядаються як ресурс, який може використовуватися для реконфігурації структури цільових систем, що забезпечить реалізацію необхідних можливостей на окремих часових фазах. При такому підході можлива реалізація нехарактерних для даної зброї функцій, наприклад стрільба артилерійських систем (не ППО) по крилатих ракетах

\section{Список літератури}

1. Carl von Clausewitz. On war / Carl von Clausewitz. - Princeton, New jersey: Princeton University Press, 1989. - 732 p.

2. Ashby W. Introduction to cybernetics / W. Ashby. - L.: Chapman \& Hall LTD, 1957. - 295 p.

3. Ярош С.П. Теоретичні основи побудови та застосування розвідувально-управляючих інформаційних систем: монографія / С.П. Ярош; за ред. І.О. Кириченка. - Х.: ХУПС, 2012. - 500 с.

4. Alberts D. Network Centric Warfare: Developing and Leveraging Information Superiority / D. Alberts, J. Garstka, F. Stein. - Washington, DC: CCRP Publication Series, 1999. - 287 p.

5. Understanding Information Age Warfare / D. Alberts, J. Garstka, R. Hayes, D. Signori. - Washington, DC: CCRP Publication Series, 2001. - 319 p.

6. Alberts D. Information Age Transformation: Getting to a 21st Century Military / D. Alberts. - Washington, DC: CCRP Publication Series, 2002. - 155 p.

7. Alberts D. Power to the Edge: Command, Control, in the Information Age / D. Alberts, R. Hayes. - Washington, DC: CCRP Publication Series, 2005. - 303 p.

8. All that glisters: Is network-centric warfare really scientific? / D. Reid, G. Goodman, W. Johnson, R. Giffin // Defense \& Security Analysis. - 2005. - № 21(4). - P. 335-367. https://doi.org/10.1080/1475179052000345403. 
9. Wilson C. CRS Report for Congress. Network Centric Operations: Background and Oversight Issues for Congress / C. Wilson. - Washington, D.C: Library of Congress. - 2007. - 121 p.

10. Арзуманян Р. Теория и принципы сетецентричных войн и операций / Р. Арзуманян // XXI век. - 2008. - № 2(8). - C. 109-149.

11. System Engineering Vision 2025. International Council on Systems Engineering [Electronic resource]. - 2014. - Available at: http://www.incose.org/.

12. Левенчук А. Системное мышление [Електронний ресурс] / А. Левенчук. - 2018. - Режим доступу: http://www.litres.ru/.

13. Gharajedaghi J. Systems Thinking: Managing Chaos and Complexity: A Platform for Designing Business Architecture / J. Gharajedaghi. - USA: Elsevier, 2011. - 376 p.

14. The Systems of Systems Engineering Strategic Research Agenda / M. Henshaw, C. Siemieniuch, M. Sinclair, V. Barot et al // VIII-th International Conference on System of Systems Engineering, USA Maui, 2-6 June 2013. https://doi.org/ 10.1109/ICSMC.2005.1571630.

15. Скорик А.О. Методологии оценки влияния сложности структуры военно-технических систем на боевой потенциал воинских формирований / А.Б. Скорик, И.Г. Кириллов, Х.А. Турсунходжаев // Системи озброєння і військова техніка. - 2010. - № 4(24). - С. 237-241.

Надійшла до редколегії 07.08.2020 Схвалена до друку 13.10.2020

Відомості про авторів:

\section{Скорик Анатолій Борисович}

кандидат технічних наук доцент

доцент кафедри

Харківського національного

університету Повітряних Сил ім. І. Кожедуба,

Харків, Україна,

https://orcid.org/0000-0002-4327-8796

\section{Ярош Сергій Петрович}

доктор військових наук професор

професор кафедри

Харківського національного університету

Повітряних Сил ім. І. Кожедуба,

Харків, Україна,

https://orcid.org/0000-0002-5208-9372

\section{Information about the authors:}

\author{
Anatolii Skoryk \\ Candidate of Technical Sciences Associate Professor \\ Senior Lecturer \\ of Ivan Kozhedub Kharkiv National \\ Air Force University, \\ Kharkiv, Ukraine \\ https://orcid.org/0000-0002-4327-8796
}

\author{
Serhii Yarosh \\ Doctor of Military Sciences Professor \\ Professor of Department \\ of Ivan Kozhedub Kharkiv \\ National Air Force University, \\ Kharkiv, Ukraine \\ https://orcid.org/0000-0002-5208-9372
}

\title{
ЭВОЛЮЦИОННОЕ РАЗВИТИЕ КОНЦЕПЦИИ СЕТЕЦЕНТРИЧЕСКИХ ВОЙН, СИСТЕМНО-КОНЦЕПТУАЛЬНЫЕ ОСНОВЫ ТЕОРИИ ДАТАЦЕНТРИЧЕСКИХ ОПЕРАЦИЙ
}

\author{
А.Б. Скорик, С.П. Ярош
}

В статье кратко обсуждаются основополагающие принципы концепщии сетецентрических войн. Делается вывод о том, что в условиях перехода человечества к 6-му технологическому укладу возникает очередная точка бифуркации, определяющая смену парадигмы развития систем ВВТ и концепции ведения боевых действий. Аргументируется необходимость развития теории датачентрической операции. Излагаются системно-концептуальные основы теории датачентрических операций. Предложена онтологическая модель датацентрической операции. Предлагается $4 D$-экстенциональное представление боевого пространства объединенных в единую сеть систем ВВТ. Вводится понятие датацентрических систем.

Ключевые слова: датацентрическая операция, сетецентрическая война, 4D-экстенционализм, системы-систем.

\section{EVOLUTIONARY DEVELOPMENT OF THE CONCEPT NETWORK-CENTRIC WARFARE, SYSTEM-CONCEPTUAL FOUNDATIONS OF THE THEORY OF DATE-CENTRAL OPERATIONS}

\author{
A. Skoryk, S. Yarosh
}

The article briefly discusses the underlying principles and evolutionary development of the concept of network-centric warfare. The conclusion is made that in the conditions of mankind's transition to the 6th technological order, another bifurcation point arises, which determines the change in the paradigm of the development of weapons and military equipment systems and the concept of warfare. The necessity of development of the theory of data-centric operation is argued. The system-conceptual foundations of the theory of data-centric operations are presented. An ontological model of a data-centric operation is proposed. The issues of creation and functioning of data-centric systems in $4 D$ space (3D coordinates / time) are considered as the main questions of the theory. The issues of conflict interaction of data-centric systems with network-centric systems are considered as separate questions of the theory. The main concepts of the theory of Data-Centric Operations are considered: variability \& agile development (metamorphism); 4Dextensionism; dualism of data-centric SoS. A 4D extensional representation of the combat space of weapons and military equipment systems united into a single network is proposed. The concept of data-centric systems is introduced. The essence of the method of adaptive space-time synthesis of their structure is revealed. The dual nature of data-centric systems is that they can be viewed simultaneously as both a fit-to-purpose system and network resources. The theory DCO assumes that the use of the new technologies increases the efficiency and effectiveness of operations due to: transition to the paradigm of multi-intelligent systems based on the socio-cultural model; dynamic reconfiguration of the data-centric SoS and systems of the operating environment, when environmental conditions change; expanding the boundaries of the system by implementing decentralized governance of the behavior of systems.

Keywords: data-centric operation, network-centric warfare, 4D-extensionalism, systems of systems, ontological model, selfsynchronization, network-intensive systems. 